\title{
Anopheles gambiae salivary protein expression modulated by wild Plasmodium falciparum infection: highlighting of new antigenic peptides as candidates of An. gambiae bites
}

Alexandra Marie ${ }^{1 *}$, Philippe Holzmuller ${ }^{2}$, Majoline T Tchioffo ${ }^{1}$, Marie Rossignol ${ }^{1}$, Edith Demettre ${ }^{3}$, Martial Seveno ${ }^{3}$, Vincent Corbel ${ }^{1,4}$, Parfait Awono-Ambéné ${ }^{5}$ Isabelle Morlais ${ }^{1,5}$, Franck Remoue ${ }^{1}$ and Sylvie Cornelie ${ }^{1,6^{*}}$

\begin{abstract}
Background: Malaria is the major parasitic disease worldwide caused by Plasmodium infection. The objective of integrated malaria control programs is to decrease malaria transmission, which needs specific tools to be accurately assessed. In areas where the transmission is low or has been substantially reduced, new complementary tools have to be developed to improve surveillance. A recent approach, based on the human antibody response to Anopheles salivary proteins, has been shown to be efficient in evaluating human exposure to Anopheles bites. The aim of the present study was to identify new An. gambiae salivary proteins as potential candidate biomarkers of human exposure to $P$. falciparum-infective bites.

Methods: Experimental infections of An. gambiae by wild P. falciparum were carried out in semi-field conditions. Then a proteomic approach, combining 2D-DIGE and mass spectrometry, was used to identify the overexpressed salivary proteins in infected salivary glands compared to uninfected An. gambiae controls. Subsequently, a peptide design of each potential candidate was performed in silico and their antigenicity was tested by an epitope-mapping technique using blood from individuals exposed to Anopheles bites.

Results: Five salivary proteins (gSG6, gSG1b, TRIO, SG5 and long form D7) were overexpressed in the infected salivary glands. Eighteen peptides were designed from these proteins and were found antigenic in children exposed to the Anopheles bites. Moreover, the results showed that the presence of wild $P$. falciparum in salivary glands modulates the expression of several salivary proteins and also appeared to induce post-translational modifications.

Conclusions: This study is, to our knowledge, the first that compares the sialome of An. gambiae both infected and not infected by wild $P$. falciparum, making it possible to mimic the natural conditions of infection. This is a first step toward a better understanding of the close interactions between the parasite and the salivary gland of mosquitoes. In addition, these results open the way to define biomarkers of infective bites of Anopheles, which could, in the future, improve the estimation of malaria transmission and the evaluation of malaria vector control tools.
\end{abstract}

Keywords: Anopheles gambiae, Wild Plasmodium falciparum, Salivary proteins, Biomarker, Infective bites, Proteomic

\footnotetext{
* Correspondence: alexandra.marie@ird.fr; sylvie.cornelie@ird.fr

${ }^{1}$ MIVEGEC (UMR IRD224 CNRS 5290 UM1-UM2), Institut de Recherche pour le développement (IRD), 911 avenue Agropolis, Montpellier cedex 5 34394,

France

${ }^{6}$ MIVEGEC- IRD- CREC, Cotonou 01 BP4414 RP, Bénin

Full list of author information is available at the end of the article
}

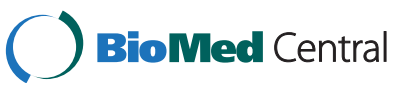

(C) 2014 Marie et al.; licensee BioMed Central. This is an Open Access article distributed under the terms of the Creative Commons Attribution License (http://creativecommons.org/licenses/by/4.0), which permits unrestricted use, distribution, and reproduction in any medium, provided the original work is properly credited. The Creative Commons Public Domain Dedication waiver (http://creativecommons.org/publicdomain/zero/1.0/) applies to the data made available in this article, unless otherwise stated. 


\section{Background}

In Sub-Saharan Africa, Anopheles gambiae is the main vector of Plasmodium falciparum, the most deadly of the five human Plasmodium species, responsible for malaria. Over half a million deaths $(627,000)$ occur every year, especially in children under 5 years of age, according to WHO [1]. Due to the lack of vaccines, the spread of resistance to anti-malaria drugs [2] and the difficulty in accessing drug treatment (the artemisinin-based combination therapies), vector control using Long Lasting Insecticide-treated Nets (LLIN) and/or Indoor Residual Spraying (IRS) still remains an important component of malaria prevention and control. However, the development of insecticide resistance in the main malaria vectors in Africa [3] is challenging the success of malaria vector control strategies $[4,5]$. In a context of malaria elimination in some areas, integrated malaria control campaigns have been implemented to reduce the malaria burden. Consequently, in these areas where transmission has substantially decreased, but also in urban settings or high-altitude areas where Anopheles exposure and malaria transmission can be very low, the current methods are not sufficiently sensitive to evaluate the human exposure to Anopheles bites and the risk of transmission. Indeed it appears difficult to obtain precise information on parasite detection and mosquito capture in these contexts so the development of appropriate tools is necessary.

One promising approach is to evaluate the real contact between the human host and the vector by measuring the human antibody $(\mathrm{Ab})$ response to specific Anopheles salivary proteins [6]. During its blood meal, mosquitoes inject saliva into the human skin, inducing a humoral response. This concept has been validated using whole saliva extracts (WSEs) of An. gambiae [6] and in other hematophagous arthropods, such as Aedes [7-9], Culex $[10,11]$, Glossina [12,13] and phlebotomine sand flies $[14,15]$. However, some salivary proteins are ubiquitous in arthropods and the response observed against WSEs could therefore reflect the exposure to numerous arthropods. For this reason, a biomarker of human exposure to bites must be directed to genus- or species-specific epitopes. Based on previous studies, the gSG6 protein has been shown to be specific to the Anopheles genus and immunogenic $[16,17]$. This protein was therefore validated as a specific biomarker of exposure to Anopheles bites in Burkina Faso [18,19] and Tanzania [20].

To optimize the specificity and the utility of the biomarker, a peptide design of this protein was performed. The gSG6-P1 peptide has been found to be antigenic and the $\mathrm{Ab}$ response to this peptide was positively associated with the level of exposure to Anopheles bites [21]. This peptide has also been validated as a biomarker in different malaria transmission areas such as rural low exposure in Senegal [22,23], in highland areas in Kenya [24], in urban settings [25] and for exposure to $A n$. funestus [26]. The limitation of this biomarker is that the $\mathrm{Ab}$ response to the gSG6 protein and the gSG6-P1 peptide may not discriminate between infective and noninfective bites, hence limiting the estimation of malaria transmission intensity. Settings of malaria transmission could be very different depending on field conditions, from unstable to stable malaria, with sporozoite rates ranging from $0.1 \%$ to $8 \%[27,28]$. In low-transmission areas, the exposure to all Anopheles bites does not accurately represent the malaria transmission risk [29]. Moreover, hotspots of malaria transmission exist in all epidemiological settings, maintaining transmission in lowtransmission seasons and fueling transmission in hightransmission seasons; the detection of these hotspots will make it possible to concentrate the integrated malaria controls [30]. Consequently, a new biomarker specific to infective bites has to be developed to assess precisely malaria risk in these particular settings and could also be useful for evaluating the efficacy of malaria control tools (drug treatments and vector controls).

The salivary glands are the crucial organ for the development and transmission of the parasite to a host. Plasmodium interacts with salivary proteins to enter salivary glands [31-34]. To survive and multiply in this organ, parasites have to counteract the immune system and use the vector's metabolism by modifying salivary protein expression [35]. Saliva is also essential for the success of blood-feeding [36], and consequently, the modification of salivary protein expression could promote parasite development and transmission. Rossignol et al., have demonstrated for the first time that the Plasmodium infection in mosquitoes decreased the expression of a salivary protein, the apyrase enzyme [37]. Transcriptomic studies have shown that genes encoding for salivary proteins were upor down-regulated in Ixodes scapularis nymphs infected by flavivirus [38], Rhipicephalus microplus infected by Anaplasma marginale [39], Culex quinquefasciatus infected by West Nile virus [40] and Aedes aegypti infected by different serotypes of dengue virus (DENV) [41]. Proteomic analyses have indicated that salivary proteins were modulated in Glossina pallipides infected by salivary gland hypertrophy virus [42], Ae. aegypti infected by DENV serotype 2 (DENV-2) [43], Ae. albopictus infected by DENV-2 [44] and Ae. aegypti infected by chikungunya virus (CHIKV) [45]. As for Plasmodium parasites, several studies have investigated the change of salivary protein expression in An. gambiae and An. stephensi infected by murine Plasmodium [46-49]. The iTRAq technique, used by Choumet et al., showed that the expression of five salivary proteins was modulated, with the ratio between infected versus non-infected salivary gland varying from 0.65 to 1.97 [46]. In a more recent study using 
the 2D-PAGE method, seven salivary proteins were shown with a modulated expression in the presence of Plasmodium berghei varying from 0.28 to 12 [47]. The present study aimed to identify salivary proteins as potential biomarkers of An. gambiae infective bites. To mimic field conditions and thereby evaluate salivary protein modulation as accurately as possible, experiments were conducted in semi-field conditions. An. gambiae mosquitoes were fed through membrane on blood containing P. falciparum gametocytes from naturally infected donors. Comparison of sialome in P. falciparum-infected versus non-infected salivary glands of $A n$. gambiae was achieved by 2D-Differential Gel Electrophoresis (2D-DIGE) and mass spectrometry (LC-MS/MS). Peptides were designed from protein candidates and their immunogenicity was tested in sera from humans living in malaria areas. These methods allowed us to select immunogenic peptides which could represent potential candidate biomarkers of An. gambiae infective bites.

\section{Methods}

\section{Ethics statements}

Experimental infections involving human subjects were approved by the Cameroonian National Ethical Committee (statement 099/CNE/SE/09). Children identified as gametocyte carriers were enrolled as volunteers after their parents or legal guardians had signed an informed consent form. Collection of human blood on filter papers was approved by the National Ethics Committee of the Senegal Ministry of Health (October 2008; 0084/MSP/DS/CNRS, ClinicalTrials.gov ID: NCT01545115). Oral and written informed consent was obtained from the children's parents or legal guardians.

\section{Mosquito strain}

The Kisumu strain of An. gambiae mosquitoes was reared in the insectary at the OCEAC (Yaounde, Cameroon). Adult mosquitoes were maintained in controlled conditions $\left(27 \pm 2^{\circ} \mathrm{C}, 85 \pm 5 \% \mathrm{RH}\right.$, and $12 \mathrm{~h}$ light/dark) and provided with a $6 \%$ sterile sucrose solution.

\section{Experimental infections}

Female mosquitoes were fed on P. falciparum gametocyte carriers. Infectious feeding was conducted as previously described [50,51]. Females, 3-5 days old, were starved for $24 \mathrm{~h}$ and allowed to feed on blood containing P. falciparum gametocytes (from 52.7 to 60.6 gametocytes $/ \mu \mathrm{L}$ ) for $35 \mathrm{~min}$. Non-infected salivary glands were obtained by feeding female mosquitoes on the blood from the same donors but heated at $43^{\circ} \mathrm{C}$ for $12 \mathrm{~min}$ for gametocyte inactivation [52]. Unfed and partially fed mosquitoes were removed by aspiration and discarded. Fully engorged females were kept in the insectary until dissections 14 days after the infectious blood meal.
Salivary glands were dissected in buffer containing Urea, 7M; Thiourea, 2M; CHAPS, 4\%. Samples were frozen individually until processing.

\section{Protein sample preparation}

Infected and non-infected salivary glands were lysed in liquid nitrogen and homogenates were then centrifuged for $20 \mathrm{~min}$ at $30,000 \times \mathrm{g}$ at $17^{\circ} \mathrm{C}$. The supernatants, called salivary gland extracts (SGEs), were collected, purified using a 2D Cleanup Kit (GE Healthcare) and protein concentrations were measured using a Coomassie Plus Protein kit (Pierce). SGEs from about 75 salivary glands were pooled to obtain $15 \mu \mathrm{g}$ of protein for each batch.

\section{D Differential Gel Electrophoresis (2D-DIGE)}

$P$. falciparum-infected and non-infected protein samples were compared using the CyDye DIGE Fluors for Ettan DIGE (GE Healthcare, Germany) for four gel replicates.

$15 \mu \mathrm{g}$ of SGE from P. falciparum-infected and noninfected samples was labeled with $150 \mathrm{pmol} / \mu \mathrm{L}$ of either Cy3 or Cy5 following the manufacturer's recommendations. An internal standard comprising $7.5 \mu \mathrm{g}$ of each SGE was labeled with Cy2. A dye swap was performed to ensure that the modifications observed between the two conditions were not due to different efficiencies in dye labeling. IEF was performed with $11 \mathrm{~cm}$ Immobiline DryStrip, pH 3-11 nonlinear (NL) (GE Healthcare, Germany). The run conditions were: current $50 \mu \mathrm{A}$ per strip; $60 \mathrm{~V}$ (step) for $1 \mathrm{~h}, 1000 \mathrm{~V}$ (gradient) for $2 \mathrm{~h}, 6000$ $\mathrm{V}$ (gradient) for $2 \mathrm{~h}$ and then $6000 \mathrm{~V}$ steps up to 30,000 Vh. The second dimension was carried out on $10-20 \%$ SDS-PAGE gels (Biorad, Marnes-la-Coquette, France) at $30 \mathrm{~V}$ for $20 \mathrm{~min}$ and then $200 \mathrm{~V}$ until the bromophenol blue front had reached the bottom of the gel. Gels were scanned using a Typhoon 9400 imager (GE Healthcare, Germany). Images were acquired at $100 \mu \mathrm{m}$ pixel resolution under non-saturating conditions and were analyzed with Progenesis Samespots 3.3 software. Statistical analysis and protein quantification were performed with ANOVA test $(p<0.005)$, which took into account the mean difference and the variance between the infected and non-infected groups. The fold change with a cut-off of 1.4-fold over- and under-expression was used. The statistical power of this study was greater than 0.9 .

\section{Protein identification by LC-MS/MS}

For the spot excision, gels were stained with the PageBlue Protein Staining Solution (Fermentas).

\section{Trypsin digestion}

Enzymatic in-gel digestion was performed according to the Shevchenko modified protocol [53]. Briefly, gel slices were destained by three washes in $50 \%$ acetonitrile, 50 $\mathrm{mM}$ triethylammonium bicarbonate buffer and incubated 
overnight at $25^{\circ} \mathrm{C}$ (with shaking) with $300 \mathrm{ng}$ trypsin (Gold, Promega, Charbonnières, France) in $100 \mathrm{mM}$ triethylammonium bicarbonate buffer. Tryptic peptides were extracted with $50 \%$ acetonitrile and 5\% formic acid, and dehydrated in a vacuum centrifuge.

\section{Nano LC-MS/MS analysis}

Peptides were solubilized in $2 \mu \mathrm{L}$ of $0.1 \%$ formic acid $2 \%$ acetonitrile and analyzed online by nano-flow HPLCnanoelectrospray ionization using a LTQ Orbitrap XL mass spectrometer (LTQ Orbitrap XL, Thermo Fisher Scientific, San Jose, CA, USA) coupled with an Ultimate 3000 HPLC (Dionex). Desalting and pre-concentration of samples were performed on-line on a Pepmap ${ }^{\circ}$ precolumn $(0.3 \mathrm{~mm} \times 10 \mathrm{~mm})$. A gradient consisting of 0 $40 \%$ B for $30 \mathrm{~min}, 80 \% \mathrm{~B}$ for $15 \mathrm{~min}(\mathrm{~A}=0.1 \%$ formic acid, $2 \%$ acetonitrile in water; $\mathrm{B}=0.1 \%$ formic acid in acetonitrile) at $300 \mathrm{~nL} / \mathrm{min}$ was used to elute peptides from the capillary $(0.075 \mathrm{~mm} \times 150 \mathrm{~mm})$ reverse-phase column (Pepmap ${ }^{\oplus}$, Dionex) fitted with an uncoated silica PicoTip Emitter (New Ojective, Woburn, MA, USA). LC-MS/MS experiments comprised cycles of five events; an MS1 scan with Orbitrap mass analysis at 60,000 resolutions followed by collision induced dissociation (CID) of the five most abundant precursors. Fragment ions generated by CID were detected at the linear trap. Normalized collision energy of $35 \mathrm{eV}$ and activation time of $30 \mathrm{~ms}$ were used for CID. All Spectra were recorded under positive ion mode using the Xcalibur 2.0.7 software (Thermo Fisher Scientific). Spectra were acquired with the instrument operating in the informationdependent acquisition mode throughout the HPLC gradient. The mass scanning range was $\mathrm{m} / \mathrm{z} 400-2000$ and standard mass spectrometric conditions for all experiments were: spray voltage, $2.2 \mathrm{kV}$; no sheath and auxiliary gas flow; heated capillary temperature, $200^{\circ} \mathrm{C}$; capillary voltage, $40 \mathrm{~V}$ and tube lens, $120 \mathrm{~V}$. For all full-scan measurements with the Orbitrap detector, a lock-mass ion from ambient air ( $\mathrm{m} / \mathrm{z} 445.120024)$ was used as an internal calibrant as described [54].

All MS/MS spectra were searched for against the Insecta entries of either SwissProt or TrEMBL databases (http:// www.uniprot.org/; v 2012_07) using the Proteome Discover software v 1.3 (Thermo Fisher Scientific) and Mascot v 2.3 algorithm (http://www.matrixscience.com/) with trypsin enzyme specificity and one trypsin missed cleavage. Carbamidomethylation was set as fixed cystein modification and oxidation was set as variable methionine modification for searches. A peptide mass tolerance or 5 ppm and a fragment mass tolerance of $0.5 \mathrm{Da}$ were allowed for identification.

Management and validation of mass spectrometry data were carried out using Proteome Discoverer software v 1.3 ( $\mathrm{p}<0.01$ for 2 peptides or more/protein).

\section{Peptide design}

The design of potential immunogenic peptides was investigated using an in silico approach. The putative B-cell epitopes were identified with the BcePred [55], ABCpred [56], BepiPred [57] and SVMTrip databases [58]. The sequences were aligned with the Blastp program in the Vectorbase database [59] and the UniProtKB database to compare the peptide sequences with known genomes or EST libraries. The peptides were selected when at least three to four algorithms predicted the same epitopes.

\section{Peptide array}

Experiments were performed with EpiFlag ${ }^{\bullet}$ methodology (Innobiochips, Lille, France). Eighteen peptides of 18-27 amino acids were synthesized by solid-phase peptide synthesis with an automated peptide synthesizer (Intavis AG, Köln, Germany) using the Fmoc/tert-butyl strategy on a $20 \mu \mathrm{mol}$ scale on a Rink-ChemMatrix ${ }^{\oplus}$ (PCAS BioMatrix Inc, Saint-Jean-sur-Richelieu, Quebec, Canada) resin. Following their elongation, peptides were deprotected and cleaved for $3 \mathrm{~h}$ at room temperature (RT) using TFA/ water/triisopropylsilane/EDT $(1850 \mu \mathrm{L} / 50 \mu \mathrm{L} / 50 \mu \mathrm{L} / 50 \mu \mathrm{L})$, precipitated in diethyl ether $/ \mathrm{n}$-heptane, $1 / 1 \mathrm{v} / \mathrm{v}$, purified by RP-HPLC on a 120- $\AA$, 5 m C18 Nucleosil column using a linear water/acetonitrile gradient containing $0.05 \%$ TFA by volume $(6 \mathrm{~mL} / \mathrm{min}$, detection at $215 \mathrm{~nm})$ and lyophilized.

Each peptide characterized by RP-HPLC and MALDITOF MS, was dissolved to a final concentration of 0.1 $\mathrm{mM}$ in $0.01 \mathrm{M} \mathrm{PBS}, \mathrm{pH} \mathrm{7.4}$, and printed on aminemodified glass slides (Arrayit, Sunnyvale, CA, USA) in duplicate.

Peptide arrays were blocked for $1 \mathrm{~h}$ at RT with PBS-M (0.01 M PBS, pH7.4, 0.05\% Tween 20 and 2.5\% non-fat milk). Saturated microarrays were washed with PBS containing $0.05 \%$ Tween 20. Human sera from Senegalese children infected by P. falciparum or not and exposed to Anopheles bites, were diluted 1:10 in PBS-M and incubated overnight at $4^{\circ} \mathrm{C}$. Microarrays were then washed three times with PBS containing 0.05\% Tween 20. After washing, the microarrays were revealed using a AlexaFluor 555-labeled goat polyclonal anti-human IgG antibody (Life Technology, Saint Aubin, France) at $1 \mu \mathrm{g} / \mathrm{mL}$ in PBS-M, for $1 \mathrm{~h}$ at RT. Microarrays were washed, rinsed with distilled water and dried. The glass slides were scanned with a TECAN LS-reloaded scanner (Tecan, Männedorf, Switzerland): $\mathrm{PMT}=150$. Data were extracted using Array-Pro ${ }^{\oplus}$ Analyzer Software.

\section{Results and discussion}

Difference in sialome profile between $P$. falciparuminfected and non-infected salivary glands of An. gambiae

The salivary glands were dissected 14 days post-infection, i.e. the time period needed for the parasites to reach the 
salivary glands. The infectious status of each pair of salivary glands was checked by quantitative PCR [60]. The differential expression of the sialome between $P$. falciparum-infected and non-infected salivary glands of $A n$. gambiae was assessed using 2D-DIGE. Overall, four biological replicates of gel were performed. After the ANOVA analysis and adjustment using the FDR approach, 207 spots showed a significant differential profile $(\mathrm{q}<0.01$ and power $>0.9$ ) with a modulation from 1.3- to 8.8-fold. Among them, 128 spots were over-expressed and 79 under-expressed. After colloidal Coomassie blue staining, 43 visible spots could be excised for LC-MS/MS identification (Figure 1A), which represent less than one third of the regulated spots and constitute an additional constraint to the identification of relevant biomarkers. Among them, 24 spots presented a 1.4 - to 2.3 -fold over-expression in $P$. falciparum-infected salivary glands, whereas 19 spots presented a 1.4- to 2.6-fold under-expression (Figure 1B). These fold changes were in accordance with another study comparing the modification of the An. gambiae sialome infected by $P$. berghei using the iTRAQ technology, in which the modulations are within the same range (from 1.5 to 1.95). However, in this previous study, the expression of only five proteins was found to be altered [46]. Another study using the An. gambiae-P. berghei experimental model has shown that the expression of seven salivary proteins was changed from 3.5- to 12-fold with the 2DPAGE technique [47]. The larger number of differentially expressed spots in the present experiment may be due to broader protein regulation upon $P$. falciparum infection or alternatively to the different techniques and protocols used between studies.
Identification of overexpressed proteins in $P$. falciparuminfected An. gambiae salivary glands

Among the 43 overexpressed spots, two proteins, the ubiquinol cytochrome $\mathrm{c}$ reductase iron-sulfur subunit and the gSG6 were found and identified, each in a single spot, as a unique protein (Figure 2 and Table 1).

The ubiquinol-cytochrome c reductase iron-sulfur subunit (Rieske subunit) is an essential component of complex III implicated in the oxidative phosphorylation. The increase in the expression of this enzyme involved in the oxidative phosphorylation has already been observed in the head of An. gambiae infected by P. berghei [61]. The presence of P. falciparum in An. gambiae could thus increase oxidative metabolism, which could be a response involved in parasite resistance.

The gSG6 protein was first identified in An. gambiae [62] but also found in An. stephensi [16] and An. funestus [63] and is specifically expressed in salivary glands in female mosquitoes [64]. This protein has not been found in Culex [65] and Aedes [66,67] mosquitoes, suggesting that it is specific to Anophelinae mosquitoes. A study has demonstrated that this protein plays a role in blood feeding [68]. In the present study, the infection of salivary glands of An. gambiae by wild P. falciparum induced overexpression of the gSG6 protein $(+1.8$-fold). However, other proteomic studies in murine models of malaria have shown that the gSG6 protein was down-regulated in $A n$. gambiae infected by $P$. berghei [46,47]. Discrepancies between studies may result from exposure to different strains of parasites. It is known that a strong relationship between pathogens and their hosts exists, which generates mutual co-evolution and co-adaptation $[52,69,70]$. In our

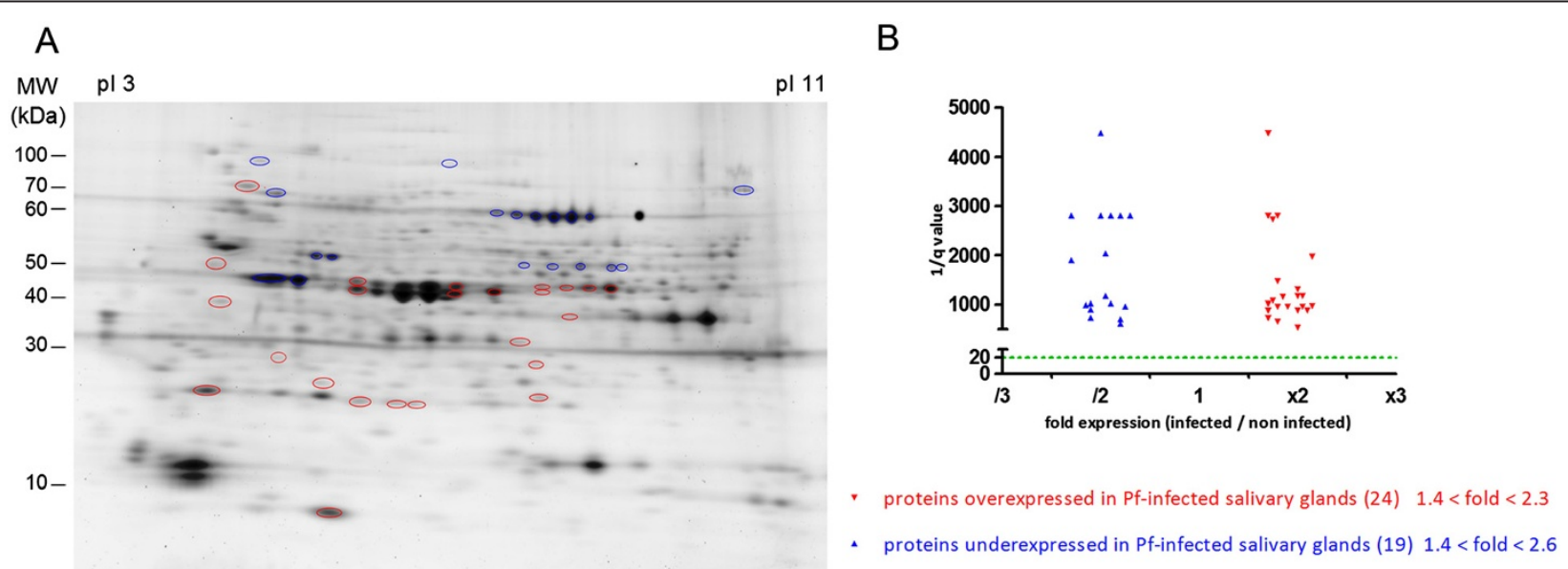

Figure 1 Differential salivary protein expression of An. gambiae infected or not infected by wild $P$. falciparum. (A) 2D-DIGE gel. Forty-three differentially expressed spots, and the only spots which have been excised, are indicated by circles. Red circles represent the 24 over-expressed spots and the 19 blue circles represent the under-expressed spots. Proteins were separated in the first dimension using carrier ampholyte gradient gels between $\mathrm{pH} 3$ and $\mathrm{pH}$ 11. The second dimension was separated using on 10-20\% SDS-PAGE gels. The isoelectric point (pl) and molecular weight scales are indicated in the figure. (B) Differences of protein expression are represented according to the expression ratio (infected/non-infected) and significance ratio (q value). The horizontal dotted line indicates the significance threshold of $q<0.05$ (or 1/q $>20$ ) according to the Samespot analysis. 


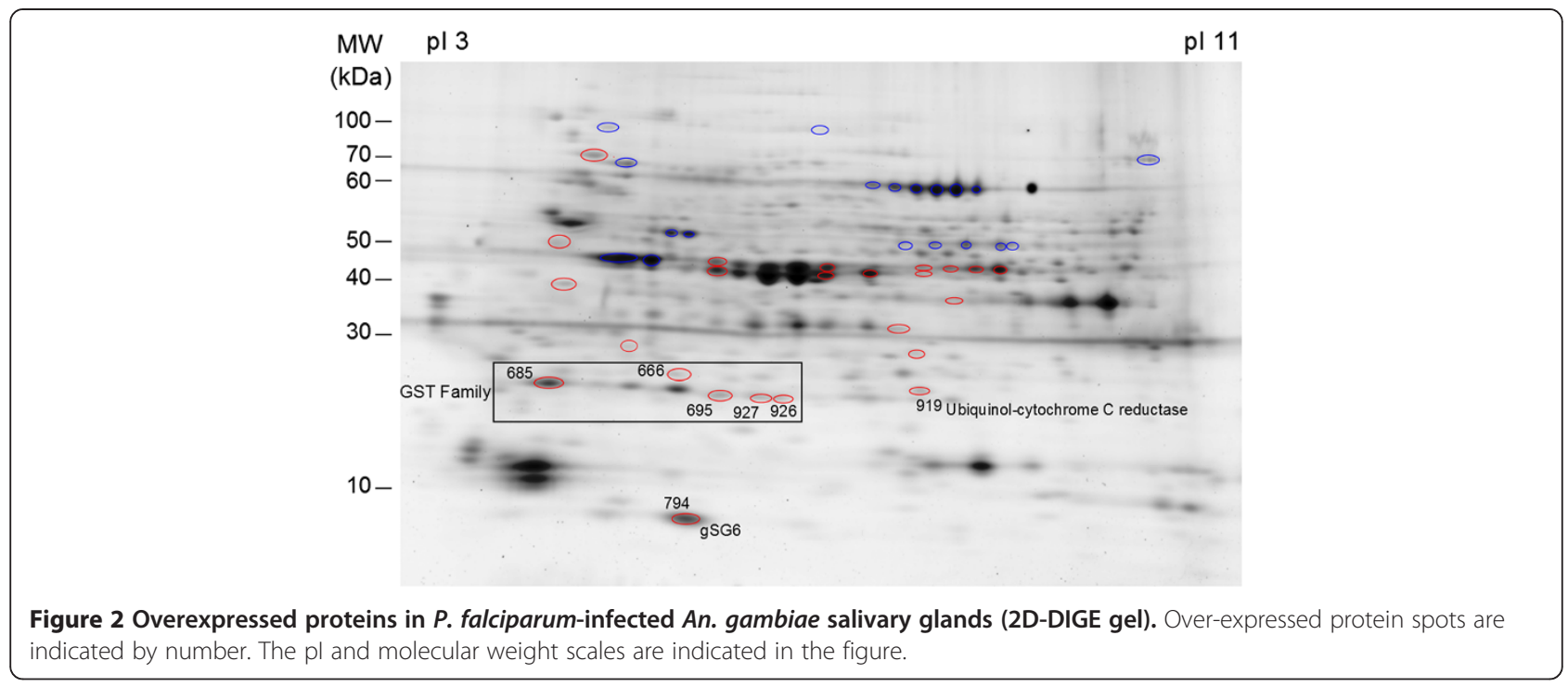

study, we used the natural model of human malaria, $A n$. gambiae and P. falciparum, whereas in the other studies $A n$. gambiae was infected by a rodent malaria parasite $P$. berghei, whose natural mosquito vector is An. dureni [71]. In addition, we used natural isolates of $P$. falciparum and parasite transmission efficiency relies on multiple factors, such as density, sex ratio or genetic complexity [52,72-74]. Interestingly, gene regulation upon P. falciparum infection in the mosquito midgut is infection intensity-dependent [52]. In the present study, the gametocyte loads in infected individuals ranged from 52.7 to 60.6 gametocytes/ $\mu \mathrm{L}$ of blood, which is low compared to parasite densities used with $P$. berghei in laboratory conditions. Differences in parasite densities within salivary glands could also lead to different levels of protein expression in the two parasite species.

In the present study, several proteins belonging to the glutathione S-transferase (GST) family were also upregulated: GST S1, GST E1, GST D1 isoform D and GST D1 isoform C. GST S1 and GST D1 isoform C were identified in several closed spots (Figure 2 and Table 1). This could be due to post-translational modifications such as glycosylation, phosphorylation and acetylation. The GST proteins are strongly involved in diverse biological processes in almost organisms such as detoxification of endogenous and xenobiotic compounds as well as in protein transport and protection against oxidative stress $[75,76]$. This protein family is conserved in the majority of arthropods such as Ae aegypti [77] and $C x$. quiquefasciatus [78]. The delta and epsilon classes of GST are insect-specific [79]. The GST D1 isoform C and $\mathrm{D}$ belongs to the delta class. These genes are rapidly diverging, suggesting a role in the adaptation of insects in different ecological niches and may be involved in the detoxification of environmental xenobiotics. This hypothesis is supported by the implication of this delta class in insecticide resistance [80]. GST E1 belongs to the epsilon class implicated in the detoxification of insecticides and in the resistance to DDT [81-83]. They also have peroxidase activity, which could be involved in

Table 1 Upregulated proteins in P. falciparum-infected An. gambiae salivary glands

\begin{tabular}{|c|c|c|c|c|c|c|c|}
\hline Spot & $\begin{array}{l}\text { Accession number } \\
\text { (UniProtKB/TrEMBL) }\end{array}$ & Protein identification & Fold & $\begin{array}{l}\text { Molecular } \\
\text { mass (kDA) }\end{array}$ & $\mathrm{pl}$ & Mascot score & $\begin{array}{l}\text { Sequence } \\
\text { coverage (\%) }\end{array}$ \\
\hline \multirow[t]{2}{*}{666} & P46428_ANOGA & GST S1 & 2.3 & 23.2 & 5.29 & 7 & 29.06 \\
\hline & Q9GPL9_ANOGA & GST E1 & & 25.3 & 5.66 & 4 & 17.86 \\
\hline 685 & P46428_ANOGA & GST S1 & 2.2 & 23.2 & 5.29 & 9 & 33.99 \\
\hline \multirow[t]{2}{*}{695} & Q93113_ANOGA & GST D1 iso D & 2.0 & 23.4 & 6.34 & 5 & 25.36 \\
\hline & Q93112_ANOGA & GST D1 iso C & & 23.8 & 6.55 & 3 & 20.57 \\
\hline 927 & Q93112_ANOGA & GST D1 iso C & 2.3 & 23.8 & 6.55 & 8 & 36.36 \\
\hline 926 & Q93112_ANOGA & GST D1 iso C & 2.0 & 23.8 & 6.55 & 5 & 17.70 \\
\hline 919 & Q7PWI1_ANOGA & Ubiquinol cyt c reductase iron sulfur subunit & 2.0 & 28.1 & 8.53 & 3 & 9.43 \\
\hline 794 & Q9BIH5_ANOGA & gSG6 & 1.8 & 13.1 & 5.49 & 14 & 45.22 \\
\hline
\end{tabular}


the protection against the secondary effects of oxidative stress [84]. The GST S1 protein belongs to the sigma class. This class of GST is found in indirect flight muscles, suggesting a structural role. However, it could also protect against the deleterious effects produced by oxidative stress [76]. It has been shown that the malaria infection in mosquito midguts induced an oxidative stress producing reactive oxygen species [85]. Consequently, the increase of GST family proteins probably counteracts the negative effects induced by the infection.

For the other spots, the identification of up- or downregulated proteins was more complex. Numerous proteins were identified in each spot, which did not allow us to determine which proteins have their expression modified (data not shown). Moreover, several proteins were found both in up- and down-regulated spots, certainly due to post-translational modifications, which made it impossible to conclude whether their expression had been modulated. However, some identified proteins in overexpressed spots involved in a glycolysis pathway (triosephosphate isomerase, fructose biphosphate aldolase, phosphoglycerate mutase and glyceraldehydes-3phosphate dehydrogenase) were also found upregulated during DENV-3 infection in the cell line of Ae. albopictus [86], DENV-2 or CHIKV-infected midgut of Ae. aegypti [45] as well as in the P. berghei-infected head of An. gambiae [61]. In addition, proteins involved in lipid metabolism were found in overexpressed spots, in agreement with a previous transcriptomic study [48]. All these studies strengthen our hypothesis that these identified proteins are probably upregulated. Moreover, these metabolic pathways are involved in energy production, which is in accordance with the over-expression of the ubiquinol-cytochrome c reductase iron-sulfur subunit. $P$. falciparum infection seems to interfere with the metabolic processes of $A n$. gambiae salivary glands. This has already been observed during the influenza virus [87] and Leishmania [88] infection.

Surprisingly, only seven $P$. falciparum proteins were found in over- and under-expressed spots (Additional file 1). This result could be due to the protein extraction protocol being insufficiently severe to disrupt sporozoites. We can also assume that the amount of salivary gland proteins was much greater resulting in a high salivary gland protein to parasite protein ratio, thus precluding the detection of the P. falciparum proteins.

\section{Identification/selection of candidate biomarkers of exposure to Anopheles infective bites}

The selection of candidates as specific biomarkers for infective bites was based on several criteria: i) overexpression, i.e. overexpressed proteins or proteins found in over-expressed spots with a high percentage of sequence coverage and a high number of identified peptides, suggesting that they are the major component of the spot; ii) potential antigenicity, i.e. inferred from the presence of a signal peptide in the protein sequence, meaning that they are secreted in the saliva and injected into the human skin during blood feeding and, as a consequence potentially induce an Ab response in humans; and iii) the specificity of proteins to the Anopheles genus. As the salivary protein candidates are overexpressed, one hypothesis could be that their antigenicity is increased, only after $P$. falciparum infection, allowing the differentiation between infective and non-infective bites. Among the overexpressed proteins mentioned above, the ubiquinol-cytochrome c reductase Rieske subunit and the GST proteins are common in many organisms and are not secreted proteins. Consequently, they are not suitable candidates for being a specific biomarker to Anopheles infected bites.

The gSG6 protein has been previously shown to be a biomarker of exposure to Anopheles bites [17-20] and some peptides have also been designed from this protein. Among them, gSG6-P1 and gSG6-P2 peptides were antigenic, but only the gSG6-P1 peptide seemed positively associated with the level of human exposure to Anopheles [21], in different exposure settings [22-25]. In the present study, the expression of the gSG6 protein was clearly increased in presence of wild P. falciparum. This result suggests that this protein could also be a potential candidate as a biomarker of infective bites. Recent studies strengthen this point by demonstrating that the $\mathrm{Ab}$ response to the gSG6 recombinant protein was associated with malaria incidence in Tanzania [20] and that the gSG6-P1 peptide could be an indicator of infection risk during the dry season (very low exposure and transmission) in northern Senegal [89].

Other candidate proteins as biomarkers were selected from some over-expressed spots: gSG1b, TRIO protein, long form D7 and SG5 (Figure 3 and Table 2). The gSG1b and TRIO proteins have already been found to be overexpressed in P. berghei-infected salivary glands of An. gambiae [47]. This result supports the finding that, in the present study, these proteins, identified among others in overexpressed spots, seem clearly upregulated. The long form D7 and SG5 proteins were selected, although their sequences matched other arthropods but with a low identity. The long form D7 protein presented $35.1 \%$ identity with Ae. Aegypti $\left(\mathrm{e}=8 \mathrm{e}^{-51}\right), 34.1 \%$ with $C x$. quiquefasciatus $\left(\mathrm{e}=5 \mathrm{e}^{-53}\right), 31.3 \%$ with G. morsitans $\left(\mathrm{e}=4 \mathrm{e}^{-04}\right)$, and $27.3 \%$ with Phlebotomus papatasi $\left(\mathrm{e}=2 \mathrm{e}^{-10}\right)$ and Lutzomia longipalpis $\left(\mathrm{e}=3 \mathrm{e}^{-11}\right)$. The SG5 presented $27.1 \%$ identity with Ae. Aegypti (e=1e-30) and $24.3 \%$ with $C x$. quiquefasciatus $(\mathrm{e}=1 \mathrm{e}-34)$. The specificity of these proteins as biomarkers of exposure to the Anopheles genus will have to be verified and, for example, an animal model of exposure could be used. The Ab response against these proteins, or peptides derived from them, can be assessed in rabbits 


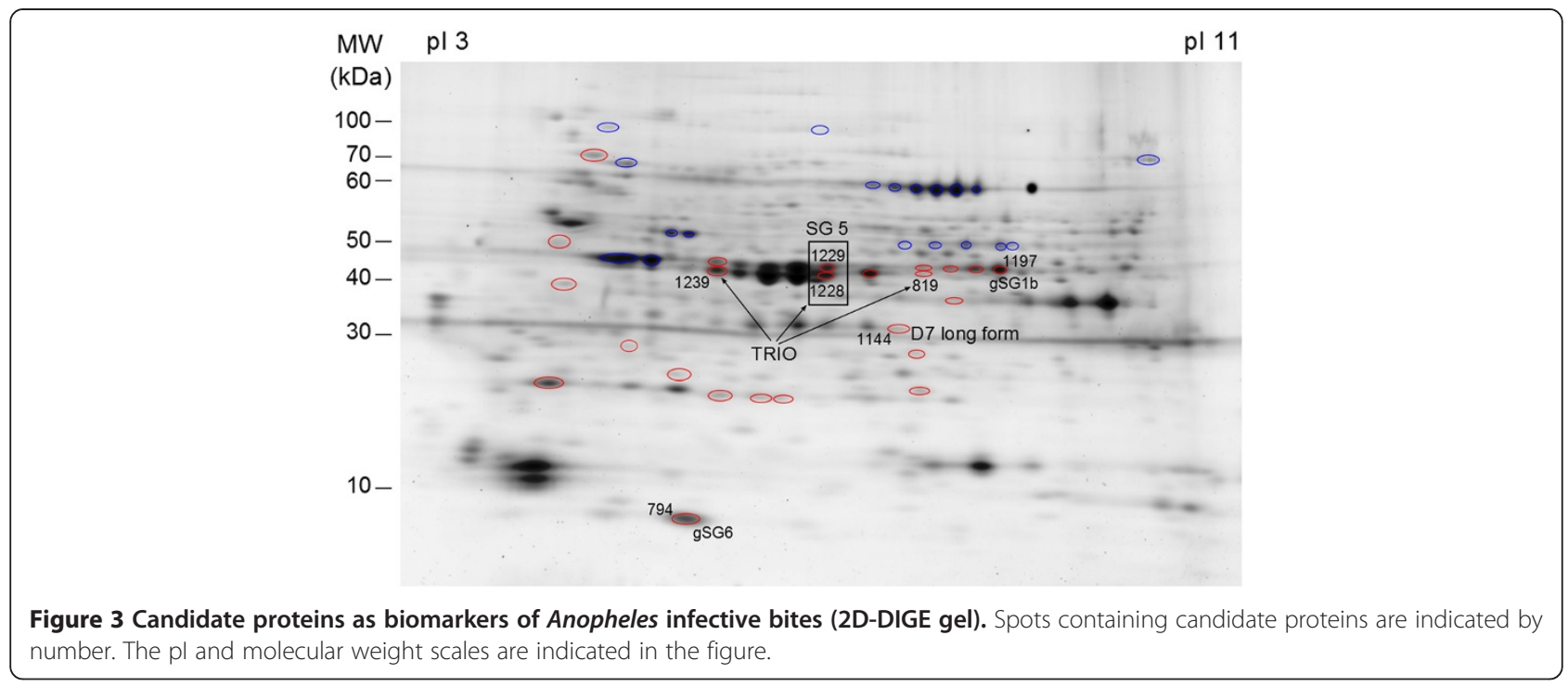

exclusively bitten by Ae. albopictus, Ae. aegypti or Cx. quiquefasciatus. However, the use of the peptides from these proteins is another approach and an opportunity to decrease the possible immune cross-reactivity.

\section{Peptide design and antigenicity of selected peptides as potential candidate biomarkers}

Aiming to optimize Anopheles specificity and to circumvent the limitations in the production of recombinant protein and batch-to-batch variations, peptides from the four previously selected proteins were designed (the gSG1b, long form D7, SG5, TRIO proteins) so as to assess their antigenic properties.

Bioinformatic tools were used to predict potential epitopes for each protein. The comparison of data generated by the four algorithms defined two peptides for gSG1b (gSG1b-P1 and gSG1b-P2), seven peptides for long form D7 (D7-P1 to D7-P7), five peptides for SG5 (SG5-P1 to SG5-P5) and two peptides for the TRIO protein (TRIO-P1 and TRIO-P2), 18-27 amino acid residues long (Table 3).
All these peptides were aligned using the Blastp program in Vectorbase to search for similarities with other hematophagous arthropods and the Blastp program in UniProtKB to search for similarities with human infectious organisms, to avoid immune cross-reactivity. No relevant identity was found, as indicated by the low scores observed (few amino acids (aa) consecutively matched and high e-value, i.e., e $>0.03$ ) (Table 4). This analysis showed that all peptides selected possessed a high specificity for the Anopheles species.

The antigenicity of these peptides was assessed using an epitope-mapping approach, with serum from children $(n=42)$ known to be exposed to Anopheles bites (Figure 4). All peptides appeared to be antigenic, but different levels of antigenicity between them were observed. The D7-P1, SG5-P2, SG5-P3, SG5-P4, SG5-P5, TRIO-P1, TRIO-P2, SG1b-P1 and SG1b-P2 peptides seemed to have a lower antigenicity than the D7-P2, D7-P3, D7-P4, D7-P5, D7-P6, D7-P7 and SG5-P1 peptides. A high antigenicity could be one of the pertinent criteria for the identification of

Table 2 Identification/selection of candidate proteins as biomarkers of Anopheles infective bites

\begin{tabular}{|c|c|c|c|c|c|c|c|c|}
\hline $\begin{array}{l}\text { Protein } \\
\text { identification }\end{array}$ & $\begin{array}{l}\text { Accession number } \\
\text { (UniProtKB/TrEMBL) }\end{array}$ & Spot & Fold & $\begin{array}{l}\text { Mascot } \\
\text { score }\end{array}$ & $\begin{array}{l}\text { Sequence coverage } \\
(\%)\end{array}$ & $\begin{array}{l}\text { Peptide } \\
\text { number }\end{array}$ & $\begin{array}{l}\text { Molecular mass } \\
(\mathrm{kDA})\end{array}$ & $\mathrm{pl}$ \\
\hline $\mathrm{gSG}^{\mathrm{SP}}$ & Q9BIH5_ANOGA & 794 & 1.8 & 14 & 45.22 & 14 & 13.1 & 5.49 \\
\hline gSG1b SP & Q9BIH6_ANOGA & 1197 & 1.6 & 59 & 46.23 & 59 & 43.6 & 7.58 \\
\hline Long form D7 SP & Q7PJ76_ANOGA & 1144 & 1.4 & 15 & 40.19 & 15 & 35.6 & 5.90 \\
\hline \multirow[t]{2}{*}{$\mathrm{SG} 5 \mathrm{SP}$} & Q9BIH7_ANOGA & 1228 & 2.0 & 15 & 29.22 & 15 & 38.2 & 6.47 \\
\hline & & 1229 & 1.6 & 14 & 29.52 & 14 & & \\
\hline \multirow[t]{4}{*}{ TRIO protein ${ }^{S P}$} & Q8WR22_ANOGA & 819 & 1.4 & 12 & 31.46 & 12 & 43.7 & 6.46 \\
\hline & & 1228 & 2.0 & 21 & 36.83 & 21 & & \\
\hline & & 1229 & 1.6 & 15 & 29.41 & 15 & & \\
\hline & & 1239 & 1.4 & 25 & 40.15 & 25 & & \\
\hline
\end{tabular}


Table 3 Peptide design of candidate proteins

\begin{tabular}{|c|c|c|c|}
\hline Protein identification & Accession number (UniProtKB/TrEMBL) & Candidate peptide biomarker & Peptide sequence \\
\hline \multirow[t]{2}{*}{$\mathrm{gSG}^{\mathrm{SP}}$} & \multirow[t]{2}{*}{ Q9BIH5_ANOGA } & gSG6-P1 & EKWWVRDNVYCGHLDCTRVATFK \\
\hline & & gSG6-P2 & ATFKGERFCTLCDTRHFCECKETREPL \\
\hline \multirow[t]{7}{*}{ Long form D7 $7^{S P}$} & \multirow[t]{7}{*}{ Q7PJ76_ANOGA } & D7-P1 & FKALDPEEAWYYYRCHEDHLPS \\
\hline & & D7-P2 & DHLPSGPNRETYLKTWKFWK \\
\hline & & D7-P3 & GLQMYDEKTNTFKPETVPVQHEAYK \\
\hline & & D7-P4 & SRKIYHGTVDSVAKIYEAKPEIKKQ \\
\hline & & D7-P5 & NKSDLEPEVRSVLASCTGTQAYDYY \\
\hline & & D7-P6 & CTGTQAYDYYSCLLNSPVKEDFRN \\
\hline & & D7-P7 & GKVYEGPEKVKEELKKLNY \\
\hline \multirow[t]{5}{*}{$\mathrm{SG} 5^{\mathrm{SP}}$} & \multirow[t]{5}{*}{ Q9BIH7_ANOGA } & SG5-P1 & GSLDPLDEEDIRTEQPTSCV \\
\hline & & SG5-P2 & VLVSIKSRMMAYTNDAVAKFEHL \\
\hline & & SG5-P3 & EECHDKLADHLAEQRREIDAAQ \\
\hline & & SG5-P4 & AEQRREIDAAQQLMGEPYRKMDG \\
\hline & & SG5-P5 & RRQLMKQNEREWEKSKS \\
\hline \multirow[t]{2}{*}{ TRIO protein ${ }^{S P}$} & \multirow[t]{2}{*}{ Q8WR22_ANOGA } & TRIO-P1 & PLTCIRWRSQNPASPAGSLGGKDW \\
\hline & & TRIO-P2 & LGGKDWSKIDAAMANFKTLF \\
\hline \multirow[t]{2}{*}{ gSG1b $b^{S P}$} & \multirow[t]{2}{*}{ Q9BIH6_ANOGA } & gSG1b-P1 & FEVCLPEIRKDPATAGLVTEV \\
\hline & & gSG1b-P2 & KKHMVASKDYESYLGALFAADA \\
\hline
\end{tabular}

SP, signal peptide.

specific biomarkers of infective bites, but the most important criterion is clearly that this biomarker can differentiate Anopheles non-infective and infective bites. Moreover, the level of the specific Ab response observed for each peptide was, for instance, scattered ranging from 2136 to 7136 fluorescence/U.A. for D7-P6 peptide and from 223.5 to 2933.5 fluorescence/U.A. for TRIO-P1 peptide. We cannot exclude that a history of human exposure to Anopheles and the immune status of these individuals could greatly contribute to the heterogeneity of the $\mathrm{Ab}$ response. The next step of this work will be to evaluate the Ab response to all these peptides on a large scale to compare their antigenicity between individuals infected by $P$. falciparum (individuals previously bitten by infected bites) and individuals exposed to Anopheles bites and identified as not infected. However, the fold over-expression of these proteins could also play a role in this differentiation. The upregulation of the selected proteins varies between 1.4 to 2.0 fold, and future studies are needed to evaluate whether this over-expression is sufficient to differentiate infective and non-infective bites. Combination of different overexpressed peptides (gSG6-P1, gSG6-P2, gSG1b-P1 and gSG1b-P2, D7-P1 to D7-P7, SG5-P1 to SG5-P5, TRIO-P1 and TRIO-P2) could increase the specificity of

Table 4 Sequence similarities of peptides with other hematophagous arthropods or human infectious organisms

\begin{tabular}{|c|c|c|c|c|c|c|c|c|}
\hline \multirow{2}{*}{$\begin{array}{l}\text { Candidat peptide } \\
\text { biomarker }\end{array}$} & \multicolumn{8}{|c|}{ Identity (amino acid consecutive, e-value) } \\
\hline & $\begin{array}{l}\text { Culex } \\
\text { quinquefasciatus }\end{array}$ & $\begin{array}{l}\text { Aedes } \\
\text { aegypti }\end{array}$ & $\begin{array}{l}\text { Glossina } \\
\text { morsitans }\end{array}$ & $\begin{array}{l}\text { Trichomonas } \\
\text { vaginalis }\end{array}$ & $\begin{array}{l}\text { Leptospira } \\
\text { weilii }\end{array}$ & $\begin{array}{l}\text { Cronobacter } \\
\text { sakazakii }\end{array}$ & $\begin{array}{l}\text { Rhodnius } \\
\text { prolixus }\end{array}$ & $\begin{array}{l}\text { Trypanosoma } \\
\text { cruzi }\end{array}$ \\
\hline D7-P1 & 4aa, e = 0.036 & $4 a a, e=0.3$ & & & & & & \\
\hline D7-P2 & & $4 a a, e=0.62$ & & & & & & \\
\hline D7-P3 & $3 a a, e=0.13$ & & & $6 a a, e=3.1$ & & & & \\
\hline D7-P5 & & & $3 a a, e=0.23$ & & & & & \\
\hline D7-P6 & $3 a a, e=0.23$ & $2 \mathrm{aa}, \mathrm{e}=0.046$ & & & & & & \\
\hline D7-P7 & & & & & $6 a a, e=0.5$ & & & \\
\hline SG5-P2 & & & & & & $8 a a, e=6.7$ & & \\
\hline SG5-P4 & & & & & & & $3 a a, e=0.25$ & \\
\hline SG5-P5 & & & & & & & & $3 a \mathrm{a}, \mathrm{e}=9$ \\
\hline
\end{tabular}




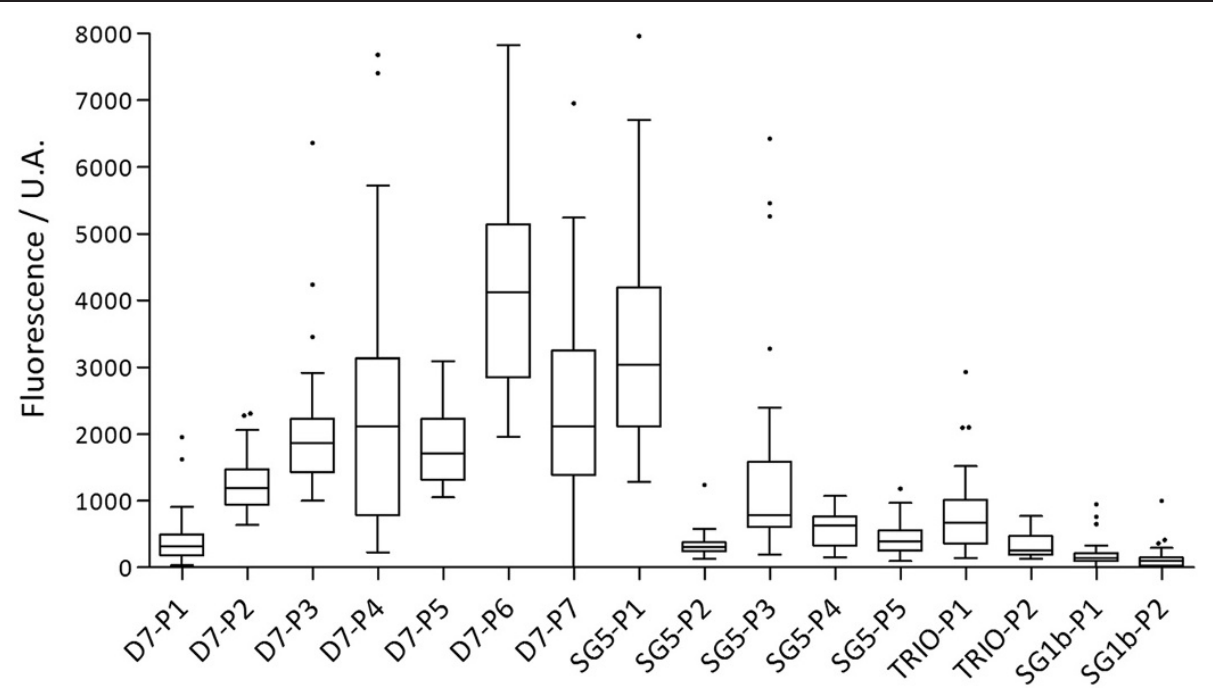

Figure $4 \mathrm{lgG}$ Ab response according to the different peptides. The lgG antibody level was evaluated in a sample of children living in Senegal exposed to Anopheles bites. Box plots display the median value, 25th and 75th percentiles. Whiskers represent 5 to 95 percentiles and dots the outliers.

Ab responses to infective bites. This strategy could also reduce the heterogeneity of $\mathrm{Ab}$ responses observed in this study. Future immunological evaluation of these peptides should be conducted using well documented cohorts either for parasitological and immunological status but also using entomological data to validate this approach.

\section{Conclusion}

The present study has provided results on the effect of the presence of the wild P. falciparum parasite on the expression of proteins in An. gambiae salivary glands. The parasite up- and down-regulates sialome expression, but also seems to induce post-translational modifications. This study and further studies will provide key elements to understand how the insect cells act to protect themselves against infection and how P. falciparum manipulates the cellular machinery of the salivary glands and the behavior of Anopheles mosquitoes.

In this study, five salivary proteins - gSG6, gSG1b, long form D7, SG5 and TRIO - were selected as potential candidate biomarkers of exposure to Anopheles infective bites in order to evaluate the risk of malaria transmission. Anopheles-specific and immunogenic peptides were designed from these proteins in silico: gSG1bP1 and gSG1b-P2, D7-P1 to D7-P7, SG5-P1 to SG5-P5, TRIO-P1 and TRIO-P2. Their immunogenicity was tested and validated using blood from children exposed to Anopheles bites. These results are the first step toward the development of a biomarker of exposure to Anopheles infective bites. This tool is essential to evaluate the malaria transmission in areas of low transmission such as urban settings, highlands and areas where the
P. falciparum transmission has been tackled by malaria control strategies. The next step will be to check whether all these peptides, in addition to gSG6-P1 and gSG6-P2, can differentiate An. gambiae-non-infective from -infective bites.

\section{Additional file}

Additional file 1: Identification of Plasmodium falciparum proteins.

\section{Abbreviations}

Ab: Antibody; WSE: Whole saliva extract; LLIN: Long lasting insecticide-treated nets; IRS: Indoor residual spraying; CHIKV: Chikungunya virus; DENV: Dengue virus; 2D-DIGE: Bidimensional differential gel electrophoresis; SGE: Salivary gland extract; GST: Glutathione S transferase; aa: Amino acid.

\section{Competing interests}

The authors declare that they have no competing interests.

\section{Authors' contributions}

AM, MR, FC, VC, IM, FR and SC designed the study and experiments. AM, MTT, PAA and IM performed the experimental infections. AM and PH carried out the proteomic experiments. MS performed the mass spectrometry analysis. $\mathrm{PH}$ and ED assisted in the gel analysis and extraction. AM, PH, MS, ED and SC analyzed the data. AM, SC and FR wrote the manuscript. All authors read and approved the final manuscript.

\section{Acknowledgments}

We thank M.N. Lacroix at Laboratoire de lutte contre les insectes nuisibles (Montpellier, France) for the mosquito collection. We are grateful to volunteers from Mfou primary schools and their parents or guardians for participating in this study, to the medical team from the Mfou hospital for assistance in the field, and to the technical staff of the OCEAC for P. falciparum infections. We are particularly grateful to Etienne Onana from the OCEAC for mosquito rearing and salivary gland dissections. We acknowledge J.P. Brizard at the UMR 5096 (IRD) for his advice on the proteomic experiments. We thank Linda Northrup for the English revision of the manuscript.

This work was funded by the Institut de Recherche pour le Développement (IRD) and the European Community's Seventh Framework Programme (FP7) (grant agreement No. 242095, EviMalaR). AM was supported by an EviMalaR 
scholarship. The funders had no role in study design, data collection and analysis, decision to publish, or preparation of the manuscript.

\section{Author details}

'MIVEGEC (UMR IRD224 CNRS 5290 UM1-UM2), Institut de Recherche pour le développement (IRD), 911 avenue Agropolis, Montpellier cedex 5 34394, France. ${ }^{2}$ CIRAD Département Systèmes Biologiques BIOS UMR 15 CMAEE "Contrôle des Maladies Exotiques et Emergentes", Campus International de Baillarguet, TA A-15/G, Montpellier cedex 5 34398, France. Institut de Génomique Fonctionnelle, CNRS UMR 5203, INSERM U661, UM1, UM2, Plate-forme de Protéomique Fonctionnelle CNRS UMS BioCampus 3426, Montpellier 34094, France. ${ }^{4}$ Department of Entomology, Faculty of Agriculture, Kasetsart University, 50 Ngam Wong Wan Rd, Ladyaow Chatuchak, Bangkok 10900, Thailand. ${ }^{5}$ Laboratoire de Recherche sur le Paludisme, Organisation de Coordination pour la lutte contre les Endémies en Afrique Centrale (OCEAC), Yaoundé BP 288, Cameroun. ${ }^{6}$ MIVEGEC- IRDCREC, Cotonou 01 BP4414 RP, Bénin.

Received: 24 June 2014 Accepted: 10 December 2014

Published online: 20 December 2014

\section{References}

1. WHO: World Malaria Report. 2013.

2. O'Brien C, Henrich PP, Passi N, Fidock DA: Recent clinical and molecular insights into emerging artemisinin resistance in Plasmodium falciparum. Curr Opin Infect Dis 2011, 24(6):570-577.

3. Ranson H, N'guessan R, Lines J, Moiroux N, Nkuni Z, Corbel V: Pyrethroid resistance in African anopheline mosquitoes: what are the implications for malaria control? Trends Parasitol 2011, 27(2):91-98.

4. Magesa SM, Aina O, Curtis CF: Detection of pyrethroid resistance in Anopheles mosquitos. Bull World Health Organ 1994, 72(5):737-740.

5. Aïkpon R, Agossa F, Ossè R, Oussou O, Aïzoun N, Oké-Agbo F, Akogbéto M: Bendiocarb resistance in Anopheles gambiae s.l. populations from Atacora department in Benin, West Africa: a threat for malaria vector control. Parasit Vectors 2013, 6:192.

6. Remoue F, Cisse B, Ba F, Sokhna C, Herve JP, Boulanger D, Simondon F: Evaluation of the antibody response to Anopheles salivary antigens as a potential marker of risk of malaria. Trans R Soc Trop Med Hyg 2006, 100(4):363-370.

7. Doucoure S, Mouchet F, Cornelie S, DeHecq JS, Rutee AH, Roca Y, Walter A, Hervé JP, Misse D, Favier F, Gasque P, Remoue F: Evaluation of the human $\lg$ antibody response to Aedes albopictus saliva as a new specific biomarker of exposure to vector bites. PLOS Negl Trop Dis 2012, 6(2):e1487.

8. Doucoure S, Mouchet F, Cournil A, Le Goff G, Cornelie S, Roca Y, Giraldez MG, Simon ZB, Loayza R, Misse D, Flores JV, Walter A, Rogier C, Herve JP, Remoue F: Human antibody response to Aedes aegypti saliva in an urban population in Bolivia: a new biomarker of exposure to Dengue vector bites. Am J Trop Med Hyg 2012, 87(3):504-510.

9. Remoue F, Alix E, Cornelie S, Sokhna C, Cisse B, Doucoure S, Mouchet F, Boulanger D, Simondon F: IgE and IgG4 antibody responses to Aedes saliva in African children. Acta Trop 2007, 104(2-3):108-115.

10. Das MK, Mishra A, Beuria MK, Dash AP: Human natural antibodies to Culex quinquefasciatus: age-dependent occurrence. J Am Mosq Control Assoc 1991, 7(2):319-321

11. Trevejo RT, Reeves WC: Antibody response to Culex tarsalis salivary gland antigens among sentinel chickens in California. Am J Trop Med Hyg 2005, 72(4):481-487.

12. Dama E, Cornelie S, Bienvenu Somda M, Camara M, Kambire R, Courtin F, Jamonneau V, Demettre E, Seveno M, Bengaly Z, Solano P, Poinsignon A Remoue F, Belem AMG, Bucheton B: Identification of Glossina palpalis gambiensis specific salivary antigens: towards the development of a serologic biomarker of human exposure to tsetse flies in West Africa. Microbes Infect 2013, 15(5):416-427.

13. Poinsignon A, Remoue F, Rossignol M, Cornelie $S$, Courtin D, Grébaut $P$, Garcia A, Simondon F: Human IgG antibody response to Glossina saliva: an epidemiologic marker of exposure to Glossina bites. Am J Trop Med Hyg 2008, 78(5):750-753.

14. Clements MF, Gidwani K, Kumar R, Hostomska J, Dinesh DS, Kumar V, Das P, Müller I, Hamilton G, Volfova V, Boelaert M, Das M, Rijal S, Picado A, Volf P, Sundar S, Davies CR, Rogers ME: Measurement of recent exposure to Phlebotomus argentipes, the vector of Indian visceral Leishmaniasis, by using human antibody responses to sand fly saliva. Am J Trop Med Hyg 2010, 82(5):801-807.

15. Martín-Martín I, Molina R, Rohoušová I, Drahota J, Volf $P$, Jiménez M: High levels of anti-Phlebotomus perniciosus saliva antibodies in different vertebrate hosts from the re-emerging leishmaniosis focus in Madrid. Spain Vet Parasitol 2014, 202(3-4):207-216.

16. Valenzuela JG, Francischetti IM, Pham VM, Garfield MK, Ribeiro JM: Exploring the salivary gland transcriptome and proteome of the Anopheles stephensi mosquito. Insect Biochem Mol Biol 2003, 33(7):717-732.

17. Orlandi-Pradines $E$, Almeras $L$, Denis de Senneville L, Barbe S, Remoue F, Villard C, Cornelie S, Penhoat K, Pascual A, Bourgouin C, Fontenille D, Bonnet J, Corre-Catelin N, Reiter P, Pages F, Laffite D, Boulanger D, Simondon F, Pradines B, Fusai T, Rogier C: Antibody response against saliva antigens of Anopheles gambiae and Aedes aegypti in travellers in tropical Africa. Microbes Infect 2007, 9(12-13):1454-1462.

18. Rizzo C, Ronca R, Fiorentino G, Verra F, Mangano V, Poinsignon A, Sirima SB, Nebie I, Lombardo F, Remoue F, Coluzzi M, Petrarca V, Modiano D, Arcà B: Humoral response to the Anopheles gambiae salivary protein gSG6: a serological indicator of exposure to Afrotropical malaria vectors. PLOS One 2011, 6(3):e17980.

19. Rizzo C, Ronca R, Fiorentino G, Mangano VD, Sirima SB, Nebie I, Petrarca V, Modiano D, Arca B: Wide cross-reactivity between Anopheles gambiae and Anopheles funestus SG6 salivary proteins supports exploitation of gSG6 as a marker of human exposure to major malaria vectors in tropical Africa. Malar J 2011, 10:206.

20. Stone W, Bousema T, Jones S, Gesase S, Hashim R, Gosling R, Carneiro I, Chandramohan D, Theander T, Ronca R, Modiano D, Arcà B, Drakeley C: IgG responses to Anopheles gambiae salivary antigen gSG6 detect variation in exposure to malaria vectors and disease risk. PLoS One 2012, 7(6):e40170.

21. Poinsignon $A$, Cornelie $S$, Mestres-Simon M, Lanfrancotti A, Rossignol M, Boulanger D, Cisse B, Sokhna C, Arca B, Simondon F, Remoue F: Novel peptide marker corresponding to salivary protein gSG6 potentially identifies exposure to Anopheles bites. PLoS One 2008, 3(6):e2472.

22. Poinsignon A, Cornelie S, Ba F, Boulanger D, Sow C, Rossignol M, Sokhna C, Cisse $B$, Simondon F, Remoue F: Human IgG response to a salivary peptide, gSG6-P1, as a new immuno-epidemiological tool for evaluating low-level exposure to Anopheles bites. Malar J 2009, 8:198.

23. Sagna AB, Sarr JB, Gaayeb L, Drame PM, Ndiath MO, Senghor S, Sow CS, Poinsignon A, Seck M, Hermann E, Schacht AM, Faye N, Sokhna C, Remoue F, Riveau G: gSG6-P1 salivary biomarker discriminates micro-geographical heterogeneity of human exposure to Anopheles bites in low and seasonal malaria areas. Parasit Vectors 2013, 6:68.

24. Badu K, Siangla J, Larbi J, Lawson BW, Afrane Y, Ong'echa J, Remoue F, Zhou G, Githeko AK, Yan G: Variation in exposure to Anopheles gambiae salivary gland peptide (gSG6-P1) across different malaria transmission settings in the western Kenya highlands. Malar J 2012, 11:318.

25. Drame PM, Machault V, Diallo A, Cornelie S, Poinsignon A, Lalou R, Sembene M, Dos Santos S, Rogier C, Pages F, Le Hesran JY, Remoue F: IgG responses to the gSG6-P1 salivary peptide for evaluating human exposure to Anopheles bites in urban areas of Dakar region. Senegal Malar J 2012, 11:72.

26. Poinsignon A, Samb B, Doucoure S, Drame PM, Sarr JB, Sow C, Cornelie S, Maiga S, Thiam C, Rogerie F, Guindo S, Hermann E, Simondon F, Dia I, Riveau G, Konate L, Remoue F: First attempt to validate the gSG6-P1 salivary peptide as an immuno-epidemiological tool for evaluating human exposure to Anopheles funestus bites. Trop Med Int Health 2010, 15(10):1198-1203.

27. Manguin S, Carnevale P, Mouchet J: Biodiversity of Malaria in the World 2008.

28. Drakeley C, Schellenberg D, Kihonda J, Sousa CA, Arez AP, Lopes D, Lines J, Mshinda H, Lengeler C, Armstrong Schellenberg J, Tanner M, Alonso P: An estimation of the entomological inoculation rate for Ifakara: a semi-urban area in a region of intense malaria transmission in Tanzania. Trop Med Int Health 2003, 8(9):767-774.

29. Beier JC, Killeen GF, Githure J: Short report: entomologic inoculation rates and Plasmodium falciparum malaria prevalence in Africa. Am J Trop Med Hyg 1999, 61(1):109-113.

30. Bousema T, Griffin JT, Sauerwein RW, Smith DL, Churcher TS, Takken W, Ghani A, Drakeley C, Gosling R: Hitting hotspots: spatial targeting of malaria for control and elimination. PLoS Med 2012, 9(1):e1001165. 
31. Sultan AA, Thathy V, Frevert U, Robson KJ, Crisanti A, Nussenzweig V, Nussenzweig RS, Ménard R: TRAP is necessary for gliding motility and infectivity of plasmodium sporozoites. Cell 1997, 90(3):511-522.

32. Brennan JD, Kent M, Dhar R, Fujioka H, Kumar N: Anopheles gambiae salivary gland proteins as putative targets for blocking transmission of malaria parasites. Proc Natl Acad Sci U S A 2000, 97(25):13859-13864.

33. Korochkina S, Barreau C, Pradel G, Jeffery E, Li J, Natarajan R, Shabanowitz J, Hunt $D$, Frevert $U$, Vernick KD: A mosquito-specific protein family includes candidate receptors for malaria sporozoite invasion of salivary glands. Cell Microbiol 2006, 8(1):163-175.

34. Wang J, Zhang Y, Zhao YO, Li MW, Zhang L, Dragovic S, Abraham NM, Fikrig E: Anopheles gambiae circumsporozoite protein-binding protein facilitates plasmodium infection of mosquito salivary glands. J Infect Dis 2013, 208(7):1161-1169.

35. Telleria EL, Benoit JB, Zhao X, Savage AF, Regmi S, Alves e Silva TL, O'Neill M, Aksoy S: Insights into the trypanosome-host interactions revealed through transcriptomic analysis of parasitized tsetse fly salivary glands. Plos Negl Trop Dis 2014, 8(4):e2649.

36. Ribeiro JM: Role of saliva in blood-feeding by arthropods. Annu Rev Entomol 1987, 32:463-478.

37. Rossignol PA, Ribeiro JM, Spielman A: Increased intradermal probing time in sporozoite-infected mosquitoes. Am J Trop Med Hyg 1984, 33(1):17-20.

38. McNally KL, Mitzel DN, Anderson JM, Ribeiro JM, Valenzuela JG, Myers TG, Godinez A, Wolfinbarger JB, Best SM, Bloom ME: Differential salivary gland transcript expression profile in Ixodes scapularis nymphs upon feeding or flavivirus infection. Ticks Tick Borne Dis 2012, 3(1):18-26.

39. Zivkovic Z, Esteves E, Almazán C, Daffre S, Nijhof AM, Kocan KM, Jongejan F, de la Fuente J: Differential expression of genes in salivary glands of male Rhipicephalus (Boophilus) microplus in response to infection with Anaplasma marginale. BMC Genomics 2010, 11:186.

40. Girard YA, Mayhew GF, Fuchs JF, Li H, Schneider BS, McGee CE, Rocheleau TA, Helmy H, Christensen BM, Higgs S, Bartholomay LC: Transcriptome changes in Culex quinquefasciatus (Diptera: Culicidae) salivary glands during West Nile virus infection. J Med Entomol 2010, 47(3):421-435.

41. Luplertlop N, Surasombatpattana P, Patramool S, Dumas E, Wasinpiyamongkol L, Saune L, Hamel R, Bernard E, Sereno D, Thomas F, Piquemal D, Yssel H, Briant L, Missé D: Induction of a peptide with activity against a broad spectrum of pathogens in the Aedes aegypti salivary gland, following Infection with Dengue Virus. PloS Pathog 2011, 7(1):e1001252.

42. Kariithi HM, Ince IA, Boeren S, Abd-Alla AM, Parker AG, Aksoy S, Vlak JM, Oers MM: The salivary secretome of the tsetse fly Glossina pallidipes (Diptera: Glossinidae) infected by salivary gland hypertrophy virus. PLoS Negl Trop Dis 2011, 5(11):e1371.

43. Wasinpiyamongkol L, Patramool S, Thongrungkiat S, Maneekan P, Sangmukdanan S, Missé D, Luplertlop N: Protein expression in the salivary glands of dengue-infected Aedes aegypti mosquitoes and blood-feeding success. Southeast Asian J Trop Med Public Health 2012, 43(6):1346-1357.

44. Zhang M, Zheng X, Wu Y, Gan M, He A, Li Z, Zhang D, Wu X, Zhan X: Differential proteomics of Aedes albopictus salivary gland, midgut and C6/ 36 cell induced by dengue virus infection. Virology 2013, 444(1-2):109-118.

45. Tchankouo-Nguetcheu S, Bourguet E, Lenormand P, Rousselle JC, Namane A, Choumet V: Infection by chikungunya virus modulates the expression of several proteins in Aedes aegypti salivary glands. Parasit Vectors 2012, 5:264.

46. Choumet V, Carmi-Leroy A, Laurent C, Lenormand P, Rousselle JC, Namane A, Roth C, Brey PT: The salivary glands and saliva of Anopheles gambiae as an essential step in the Plasmodium life cycle: a global proteomic study. Proteomics 2007, 7(18):3384-3394.

47. Zocevic A, Carmi-Leroy A, Sautereau J, d'Alayer J, Lenormand P, Rousselle JC, Namane A, Choumet V: New markers in Anopheles gambiae salivary glands after Plasmodium berghei infection. Vector Borne Zoonotic Dis 2013, 13(2):119-127.

48. Rosinski-Chupin I, Briolay J, Brouilly P, Perrot S, Gomez SM, Chertemps T, Roth CW, Keime C, Gandrillon O, Couble P, Brey PT: SAGE analysis of mosquito salivary gland transcriptomes during Plasmodium invasion. Cell Microbiol 2007, 9(3):708-724.

49. Dixit R, Sharma A, Mourya DT, Kamaraju R, Patole MS, Shouche YS: Salivary gland transcriptome analysis during Plasmodium infection in malaria vector Anopheles stephensi. Int J Infect Dis 2009, 13(5):636-646.

50. Harris C, Lambrechts L, Rousset F, Abate L, Nsango SE, Fontenille D, Morlais I, Cohuet A: Polymorphisms in Anopheles gambiae immune genes associated with natural resistance to Plasmodium falciparum. PLOS Pathog 2010, 6(9):e1001112

51. Mendes AM, Schlegelmilch T, Cohuet A, Awono-Ambene P, De lorio M, Fontenille D, Morlais I, Christophides GK, Kafatos FC, Vlachou D: Conserved mosquito/parasite interactions affect development of Plasmodium falciparum in Africa. PLoS Pathog 2008, 4(5):e1000069.

52. Mendes AM, Awono-Ambene PH, Nsango SE, Cohuet A, Fontenille D, Kafatos FC, Christophides GK, Morlais I, Vlachou D: Infection intensity-dependent responses of Anopheles gambiae to the African malaria parasite Plasmodium falciparum. Infect Immun 2011, 79(11):4708-4715.

53. Wilm M, Shevchenko A, Houthaeve T, Breit S, Schweigerer L, Fotsis T, Mann M: Femtomole sequencing of proteins from polyacrylamide gels by nano-electrospray mass spectrometry. Nature 1996, 379(6564):466-469.

54. Olsen JV, de Godoy LM, Li G, Macek B, Mortensen P, Pesch R, Makarov A, Lange $\mathrm{O}$, Horning S, Mann M: Parts per million mass accuracy on an Orbitrap mass spectrometer via lock mass injection into a C-trap. Mol Cell Proteomics 2005, 4(12):2010-2021.

55. Saha S, Raghava GP: BcePred: Prediction of Continuous B-Cell Epitopes in Antigenic Sequences Using Physico-chemical Properties. In: Artificial immune system: Springer: Verlag Berlin Heidelberg; 2004: 197-204.

56. Saha S, Raghava GP: Prediction of continuous B-cell epitopes in an antigen using recurrent neural network. Proteins 2006, 65(1):40-48.

57. Larsen JE, Lund $\mathrm{O}$, Nielsen M: Improved method for predicting linear B-cell epitopes. Immunome Research 2006, 2:2, doi:10.1186/1745-7580-2-2.

58. Yao B, Zhang L, Liang S, Zhang C: SVMTriP: a method to predict antigenic epitopes using support vector machine to integrate tri-peptide similarity and propensity. PLoS One 2012, 7(9):e45152.

59. Lawson D, Arensburger P, Atkinson P, Besansky NJ, Bruggner RV, Butler R, Campbell KS, Christophides GK, Christley S, Dialynas E, Emmert D, Hammond M, Hill CA, Kennedy RC, Lobo NF, MacCallum MR, Madey G, Megy K, Redmond S, Russo S, Severson DW, Stinson EO, Topalis P, Zdobnov EM, Birney E, Gelbart WM, Kafatos FC, Louis C, Collins FH: VectorBase: a home for invertebrate vectors of human pathogens. Nucleic Acids Res 2007, 35(Database issue):D503-D505.

60. Marie A, Boissière A, Tsapi MT, Poinsignon A, Awono-Ambéné PH, Morlais I, Remoue F, Cornelie S: Evaluation of a real-time quantitative PCR to measure the wild Plasmodium falciparum infectivity rate in salivary glands of Anopheles gambiae. Malar J 2013, 12:224.

61. Lefevre T, Thomas F, Schwartz A, Levashina E, Blandin S, Brizard JP, Le Bourligu L, Demettre E, Renaud F, Biron DG: Malaria Plasmodium agent induces alteration in the head proteome of their Anopheles mosquito host. Proteomics 2007, 7(11):1908-1915.

62. Lanfrancotti A, Lombardo F, Santolamazza F, Veneri M, Castrignano T, Coluzzi M, Arca B: Novel cDNAs encoding salivary proteins from the malaria vector Anopheles gambiae. FEBS Lett 2002, 517(1-3):67-71.

63. Calvo E, Dao A, Pham VM, Ribeiro JM: An insight into the sialome of Anopheles funestus reveals an emerging pattern in anopheline salivary protein families. Insect Biochem Mol Biol 2007, 37(2):164-175.

64. Francischetti IM, Valenzuela JG, Pham VM, Garfield MK, Ribeiro JM: Toward a catalog for the transcripts and proteins (sialome) from the salivary gland of the malaria vector Anopheles gambiae. J Exp Biol 2002, 205(Pt 16):2429-2451.

65. Ribeiro JM, Charlab R, Pham VM, Garfield M, Valenzuela JG: An insight into the salivary transcriptome and proteome of the adult female mosquito Culex pipiens quinquefasciatus. Insect Biochem Mol Biol 2004, 34(6):543-563.

66. Arca B, Lombardo F, Francischetti IM, Pham VM, Mestres-Simon M, Andersen $J F$, Ribeiro JM: An insight into the sialome of the adult female mosquito Aedes albopictus. Insect Biochem Mol Biol 2007, 37(2):107-127.

67. Ribeiro JM, Arca B, Lombardo F, Calvo E, Phan VM, Chandra PK, Wikel SK: An annotated catalogue of salivary gland transcripts in the adult female mosquito. Aedes aegypti. BMC Genomics 2007, 8:6.

68. Lombardo F, Ronca R, Rizzo C, Mestres-Simòn M, Lanfrancotti A, Currà C, Fiorentino G, Bourgouin C, Ribeiro JM, Petrarca V, Ponzi M, Coluzzi M, Arcà B: The Anopheles gambiae salivary protein gSG6: an anopheline-specific protein with a blood-feeding role. Insect Biochem Mol Biol 2009, 39(7):457-466.

69. Bongfen SE, Laroque A, Berghout J, Gros P: Genetic and genomic analyses of host-pathogen interactions in malaria. Trends Parasitol 2009, 25(9):417-422.

70. Harris C, Morlais I, Churcher TS, Awono-Ambene P, Gouagna LC, Dabire RK, Fontenille D, Cohuet A: Plasmodium falciparum produce lower infection intensities in local versus foreign Anopheles gambiae populations. PLoS One 2012, 7(1):e30849. 
71. Yoeli M, Most H, Boné G: The natural history of Plasmodium berghei in the field and under experimental conditions. Ann Soc Belges Med Trop Parasitol Mycol 1965, 45(3):267-272.

72. Bousema T, Dinglasan RR, Morlais I, Gouagna LC, van Warmerdam T, Awono-Ambene PH, Bonnet S, Diallo M, Coulibaly M, Tchuinkam T, Mulder B, Targett G, Drakeley C, Sutherland C, Robert V, Doumbo O, Touré Y, Graves PM, Roeffen W, Sauerwein R, Birkett A, Locke E, Morin M, Wu Y, Churcher TS: Mosquito feeding assays to determine the infectiousness of naturally infected Plasmodium falciparum gametocyte carriers. PLoS One 2012, 7(8):e42821.

73. Mitri C, Thiery I, Bourgouin C, Paul RE: Density-dependent impact of the human malaria parasite Plasmodium falciparum gametocyte sex ratio on mosquito infection rates. Proc Biol Sci 2009, 276(1673):3721-3726.

74. Nsango SE, Abate L, Thoma M, Pompon J, Fraiture M, Rademacher A, Berry A, Awono-Ambene PH, Levashina EA, Morlais I: Genetic clonality of Plasmodium falciparum affects the outcome of infection in Anopheles gambiae. Int J Parasitol 2012, 42(6):589-595.

75. Hayes JD, Pulford DJ: The glutathione S-transferase supergene family: regulation of GST and the contribution of the isoenzymes to cancer chemoprotection and drug resistance. Crit Rev Biochem Mol Biol 1995, 30(6):445-600

76. Singh SP, Coronella JA, Benes H, Cochrane BJ, Zimniak P: Catalytic function of Drosophila melanogaster glutathione S-transferase DmGSTS1-1 (GST-2) in conjugation of lipid peroxidation end products. Eur J Biochem 2001, 268(10):2912-2923.

77. Lumjuan N, Stevenson BJ, Prapanthadara LA, Somboon P, Brophy PM, Loftus BJ, Severson DW, Ranson H: The Aedes aegypti glutathione transferase family. Insect Biochem Mol Biol 2007, 37(10):1026-1035.

78. Niranjan Reddy BP, Prasad GB, Raghavendra K: In silico characterization and comparative genomic analysis of the Culex quinquefasciatus glutathione S-transferase (GST) supergene family. Parasitol Res 2011, 109(4):1165-1177.

79. Fournier D, Bride JM, Poirie M, Bergé JB, Plapp FW: Insect glutathione S-transferases. Biochemical characteristics of the major forms from houseflies susceptible and resistant to insecticides. J Biol Chem 1992, 267(3):1840-1845.

80. Vontas JG, Small GJ, Nikou DC, Ranson H, Hemingway J: Purification, molecular cloning and heterologous expression of a glutathione S-transferase involved in insecticide resistance from the rice brown planthopper, Nilaparvata lugens. Biochem J 2002, 362(Pt 2):329-337.

81. Ding Y, Ortelli F, Rossiter LC, Hemingway J, Ranson H: The Anopheles gambiae glutathione transferase supergene family: annotation, phylogeny and expression profiles. BMC Genomics 2003, 4(1):35.

82. Lumjuan N, McCarroll L, Prapanthadara LA, Hemingway J, Ranson H: Elevated activity of an Epsilon class glutathione transferase confers DDT resistance in the dengue vector. Aedes aegypti. Insect Biochem Mol Biol 2005, 35(8):861-871.

83. Ranson $H$, Rossiter L, Ortelli F, Jensen B, Wang X, Roth CW, Collins FH, Hemingway J: Identification of a novel class of insect glutathione S-transferases involved in resistance to DDT in the malaria vector Anopheles gambiae. Biochem J 2001, 359(Pt 2):295-304.

84. Ortelli F, Rossiter LC, Vontas J, Ranson H, Hemingway J: Heterologous expression of four glutathione transferase genes genetically linked to a major insecticide-resistance locus from the malaria vector Anopheles gambiae. Biochem J 2003, 373(Pt 3):957-963.

85. Kumar S, Christophides GK, Cantera R, Charles B, Han YS, Meister S, Dimopoulos G, Kafatos FC, Barillas-Mury C: The role of reactive oxygen species on Plasmodium melanotic encapsulation in Anopheles gambiae. Proc Natl Acad Sci U S A 2003, 100(24):14139-14144.

86. Patramool S, Surasombatpattana $P$, Luplertlop N, Sévéno M, Choumet V, Thomas F, Missé D: Proteomic analysis of an Aedes albopictus cell line infected with Dengue serotypes 1 and 3 viruses. Parasit Vectors 2011, 4:138.

87. Ritter JB, Wahl AS, Freund S, Genzel Y, Reichl U: Metabolic effects of influenza virus infection in cultured animal cells: Intra- and extracellular metabolite profiling. BMC Syst Biol 2010, 4:61
88. Rabhi I, Rabhi S, Ben-Othman R, Rasche A, Daskalaki A, Trentin B, Piquemal D, Regnault B, Descoteaux A, Guizani-Tabbane L, Sysco Consortium: Transcriptomic signature of Leishmania infected mice macrophages: a metabolic point of view. PLoS Negl Trop Dis 2012, 6(8):e1763.

89. Sagna AB, Gaayeb L, Sarr JB, Senghor S, Poinsignon A, Boutouaba-Combe S, Schacht AM, Hermann E, Faye N, Remoue F, Riveau G: Plasmodium falciparum infection during dry season: IgG responses to Anopheles gambiae salivary gSG6-P1 peptide as sensitive biomarker for malaria risk in Northern Senegal. Malar J 2013, 12(1):301.

doi:10.1186/s13071-014-0599-y

Cite this article as: Marie et al:: Anopheles gambiae salivary protein expression modulated by wild Plasmodium falciparum infection: highlighting of new antigenic peptides as candidates of An. gambiae bites. Parasites \& Vectors 2014 7:599.

\section{Submit your next manuscript to BioMed Central and take full advantage of:}

- Convenient online submission

- Thorough peer review

- No space constraints or color figure charges

- Immediate publication on acceptance

- Inclusion in PubMed, CAS, Scopus and Google Scholar

- Research which is freely available for redistribution

Submit your manuscript at www.biomedcentral.com/submit
C) BioMed Central 